\title{
Understanding intentions towards seeking university-business partnerships - analysing four European cases
}

\author{
Katalin Czako \\ Széchenyi István University, \\ Györ, Hungary \\ ckatalin@sze.bu
}

ORCID 0000-0001-9373-051X

\author{
Zsolt Kohus \\ Széchenyi István University, \\ Györ, Hungary \\ zsolt.kobus@gmail.com
}

\section{Zoltán Baracskai}

Széchenyi István University,

Györ, Hungary

baracskai.zoltan@sze.hu

Abstract. It is an important economic and social issue for universities to provide value for their communities by seeking and maintaining partnerships with local firms. This paper analyses institutions of different national economies. It systematises the differences and similarities in the communication of universities aiming to partnering. To this end, we present four European cases from France, Germany, Hungary and Poland. The methodology lies in its grounded theory approach to a continuous multi-case analysis. Our hypotheses are as follows: There are role differences of universities in the observed cases (H1). There are different understandings behind fruitful university-business partnerships (H2). The rate of diversification in local industries effects the presence and types of university services and business partnering activity (H3). Data hubs were extracted from institutional communications and integrated with local economic data input. The novel approach of applying the grounded theory supports complex observation. Notions of fruitful partnerships are institution-specific, but we identify two opposite perspectives of strategies to run efficient university-business partnering. The structure of the local industrial environment, research output and university-business interactions have definable mutual effects.

Keywords: universities, partnerships, entrepreneurial ecosystem, economic issues of 
education, grounded theory.

JEL Classification: I23, I25, A20

\section{INTRODUCTION}

The European University Association states in its report that universities in Europe follow similar strategic directions of management in their business relation. Beside this, a study says, that the industrial environment and local partnerships shape these directions differently (Uslu, 2018). The economic and social issues of education are of key importance in Europe as it has the longest history and evolution. This paper examines these issues through a study of the communication of four European universities to reveal different strategic perspectives in partnering. Universities are moving between the society and economy as they provide professionals from the society to the economy. If we focus on local economy, universities are of key importance as their operational key success factor is to provide local industries with future successful professionals. In addition, through their firm partnering activity, they are significant players of social economy, because their entrepreneurial, not-for-profit operation can shape local industry. In order to discover how close higher educational institutions and economic players are to each other, we focus on four European cases: Hungary, Germany, France, and Poland. The chosen universities implement the "entrepreneurial university" approach at a strategic level based on logic of Clark (1998). Sharing the ideas of Etzkowitz (2004), we emphasize the transformation in the communication of universities. In doing so, we ask the following basic question: How can these universities determine and adapt their best practices and tools in their particular stage of development? Similar to Fuller et al. (2018), we explore and compare the third-stream and enterprising activities of the selected universities. The goal of the paper is to provide a complex overview at the institutional level and to identify differences. Our hypotheses are as follows: There are role differences of universities in the observed cases $(\mathrm{H} 1)$. There are different understandings behind fruitful university-business partnerships (H2). The rate of diversification in local industries effects the presence and types of university services and business partnering activity (H3). Following the logic of the grounded theory and concept identified in the literature, we define two main categories of the data collected for comparison. The first category considers external research perspectives. We present data collected from historical, institutional and industrial environments. The second category considers internal factors of research perspectives. The collected data concern service placement, type of services, formalized long-term relations, differentiation between educational services and contact information. This background provides the basis of our comparisons.

\section{LITERATURE REVIEW}

Clark's (1998) notion of entrepreneurial universities was further developed by a Hungarian researcher Inzelt (2004), who examined how partnership among governmental facilities, universities, industries and companies contributes to the entrepreneurial transition of universities. We highlight the importance of development peripheries, with a focus on industrial, business or technology parks and special departments for development services and research activities with high financial autonomy (Guadix et al. 2016). Through these entities, the university and its environment create a matrix structure where researchers contribute to the university-industry knowledge transfer as it stated by Ferreira and Carayannis (2019). We think, that this shapes the university-business relations as well. Powers and McDougall (2005) also says, that in this context, managers and academicians are the main players contributing to the transformation of the traditional university. There are different viewpoints on an entrepreneurial university and its third 
mission. While Clark (1998) listed the common characteristics, Benneworth et al. (2015) called attention to the tensions in the third mission and assume that institutionalising the third mission depends on external stakeholders. In addition to other multi-case evaluations (Calrk, 1998; Inzelt, 2004; Fuller et al., 2018), Cunningham and O'Reilly (2018) performed a detailed literature review and identified macro, meso and micro perspectives of technology transfer. Motivated by this, we follow the logic of external and internal factors in research categories, and refer to "institutional relations" as an external influencing category and "university-business interactions" as an internal influencing category.

\subsection{External factors in the entrepreneurial environment}

Highlighting the external research perspectives, Guerrero et al. (2016) explored the impact of a university's entrepreneurial activity on regional competitiveness by building a conceptual framework from formal and informal factors supporting entrepreneurial universities. They reached the conclusion that a favourable entrepreneurial university environment has a positive effect on the university's regional contribution in the field of social indicators such as employment. Kedziora et al. (2017) analysed how offshored educational functions effect organizations. Fekete $(2015,2017,2018)$ identified different university roles in the local governance of post-socialist countries. Filipetti and Savona (2017) focused on a different level of academic engagement and explored the barriers of university-business linkages. They indicated that these barriers include the incentives and behaviours of individual academic entrepreneurs; company barriers to cooperate with public research institutions; and individual behaviours, incentives and organizational bottlenecks in late-developing countries.

\subsection{Internal factors in the entrepreneurial environment}

Fruitful business partnering should currently be addressed in the higher education system as a basic focal point. Stankevičienè et al. (2019) evaluate university technology transfer comprehensively. In addition to entrepreneurial success, Carattoli (2017) analysed the social ties, actors and other specific aspects of Argentinian universities. A valuable finding was that stronger ties resulted in knowledge benefits for the analysed university and weaker ties provided financial benefits through university services. Turning to personal-level perspectives, Czarnitzki et al. (2015) observed a relationship between the denial of research outputs and the joint research financed by industry: scientists who received external funds were more likely to deny research outputs than other scientists, which suggests policy implications for governing the sharing behaviour of researchers. University knowledge, creativity, innovation, as well as intangible assets and intellectual capital are in a good position for the sustainable development of a given ecosystem (Glaser et al. 2014). According to Etzkowitz \& Leydesdorff (1997) and Laredo (2007), universities provide the necessary knowledge to create and boost innovation capacity for local and global businesses. Thus, universities are shifting from the two-core mission of teaching and research into a more complex entrepreneurial model, and actively contribute to the development of the given region, both in short- and long-term (Etzkowitz \& Leydesdorff, 2000; Etkowitz, 2003).

The term of university-industry collaboration is classified in different ways (Piirainen, Andersen \& Andersen, 2016; Ankrah \& Al-Tabbaa, 2015) and can be described by several indicators, such as the number of patents/intellectual property rights, the number of publications and learning metrics (Perkmann et al., 2011). The outcomes of these university-industry collaborations are a crucial indicator (Pertuzé et al. 2010), however, to our best knowledge, their availability causes difficulties for the analysis of university-industry cooperation. To overcome this problem, we also used an explicit indicator of university-industry collaboration, the evolution of joint publications for the selected universities between 2015-2019. As a resource, we used the Web of Science database. We were motivated by the works of 
Tijssen (2012) and Tijssen et al. (2009) who have shown, that at large universities the co-publications can reflect knowledge co-production and knowledge flow to industry. It has been highlighted by Kohus et al. (2020), that the analysis of university-industry co-publications, even for lack of major indicators of this cooperation, could be used as a potential tool to characterize university-industry interaction.

\section{METHODOLOGICAL APPROACH}

As it was mentioned before, data collection protocol is following the grounded theory approach. Its logic allows for systematised data collection, which is suitable for theory creation and coding with empirically valid findings (Martin and Turner, 1986). According to the original concept of grounded theory (Glaser and Strauss, 1967) it provides a constant comparative method for scientific activity that accepts qualitative, quantitative and hybrid data collection from case studies (Glaser, 1998). Grounded theory was first applied in sociology but spread to marketing and management studies and regional case study analyses. Components of grounded theory study were identified by Sbaraini et al. (2011) in the context of medical research. Charmaz $(2003,2006)$ evaluated and summarized the protocol of category definition, data collection and theory creation in grounded theory. He took a grounded theory approach and continuously analysed and interpreted the data. His goal was to determine the direction of further data collection while continuously improving and refining the theoretical framework. Following this approach, data collection and data analysis go hand in hand, and they build on each other in this paper as well. Case studies supported by a grounded theory approach have rarely been carried out in the field of entrepreneurial or industrial environment research, but Charmaz filled this gap. However, a significant part of the entrepreneurial university or university-business linkages in the extant literature is based on single cases (Algieri et al. 2013, Jacob et al. 2003, Rasmussen-Rice 2011, Ferreira-Ramos 2015, Martinelli et al. 2008). To address this gap, several researchers have aimed to apply systematic, multi-case evaluations and analyse qualitative data (Clark, 1998; Barnes et al., 2002; Guerrero and Urbano, 2012). Glaser and Strauss's grounded theory concept provides an opportunity to assess comparative studies in many research fields (Glaser, 1998; Glaser-Strauss, 2017). We applied the coding logic of grounded theory in analysing the business partnering activity of universities. It is suitable for that to achieve objective comparison as grounded theory has quite simple coding process. Firstly, we had to define two general categories, which involve already presented and operating elements (data hubs) in and around universities supporting the business partnering activity. We focused on those elements, which have significant role in the communication of business partnering. With this approach, we could extract those parts of university communication, through which these institutions express their business-partnering activity. At the same time, we could observe different the forms, rates, places and functions of these parts. To do so, we expected to make objective comparison.

\subsection{Categories}

Considering the methodology and the highlighted research perspectives, we choose two influencing categories. We code Category 1 as institutional relations and Category 2 as university-business interactions. In the processed case studies, these two categories are observed in greater depth through the application of two data analysis steps (Figure 1). The data hubs listed in Figure 2 are linked to the categories. These are based on the information collected from the first and second steps of data collection (the data collection methodology is described in the following section). 


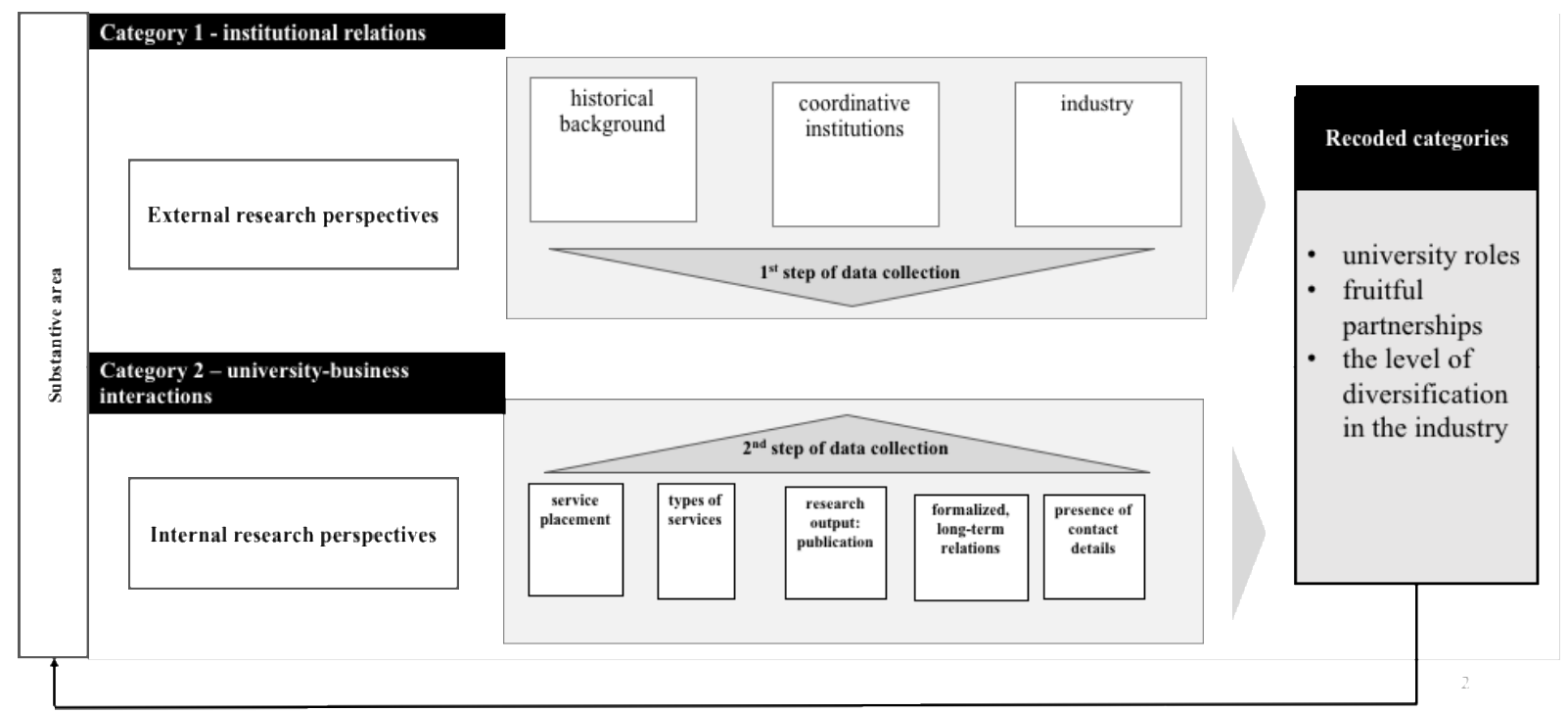

Figure 1. Research concept: Coding categories and steps of data collection

Source: own compilation

The grounded theory approach to case study analysis allows us to systemize commonalities or discover differences among the cases. Focusing on Category 1 and Category 2, we highlight conclusions regarding university roles, the success of partnerships and the interdependence with the level of diversification in the local industry. These conclusions are critical methodological and empirical contributions to the theory of the operation of entrepreneurial universities.

\subsection{Data hubs}

To adhere to the requirement of extensive data collection, we incorporated a qualitative database into the data hubs as illustrated in Figure 2. A two-step data collection was applied (Table 1).

Table 1

Data collection and analysis with data hubs representing university-business partnering from communication point of view

\begin{tabular}{|c|c|c|c|}
\hline Categories & Data hubs* & Collection & Conclusion \\
\hline \multirow{3}{*}{$\begin{array}{l}\text { 1. Institutional } \\
\text { relations }\end{array}$} & 1. Historical background & \multirow{3}{*}{$\begin{array}{l}1 \text { st step: Observation of local } \\
\text { processes in } 19 \text { cities of } 9 \text { European } \\
\text { countries }\end{array}$} & \multirow{8}{*}{$\begin{array}{l}\text { Recoded Categories: } \\
\text { Determination of case } \\
\text { specifics: } \\
\text { Differences in } \\
\text { university roles. } \\
\text { Fruitful partnerships. } \\
\text { Interdependences - } \\
\text { diversification among } \\
\text { industries. } \\
\text { Interdependencies - } \\
\text { research output. }\end{array}$} \\
\hline & $\begin{array}{l}\text { 2. Coordinative } \\
\text { institutions }\end{array}$ & & \\
\hline & 3. Industry & & \\
\hline \multirow{5}{*}{$\begin{array}{l}\text { 2. University-business } \\
\text { interactions }\end{array}$} & 1. Service placement & \multirow{5}{*}{$\begin{array}{l}2^{\text {nd }} \text { step: Notes from university } \\
\text { websites, university documents, local } \\
\text { news, WoS. }\end{array}$} & \\
\hline & 2. Service types & & \\
\hline & 3. Publication output & & \\
\hline & $\begin{array}{l}\text { 4. Nr. of formalized, } \\
\text { long term interaction. }\end{array}$ & & \\
\hline & 5. Contact details & & \\
\hline
\end{tabular}

Source: own design

Serving the dominant view of existing literature, we defined "external relations" as external factor in a university's institutional ecosystem. Beside this category, historical background is significant, because this can be the base of the present institutional communication strategies. It was important to see the age of 
the institutions and their evolutions. We collected the cornerstones in the institutions' life. It was interesting to see, how the local economy shapes the development projects and their outcomes for long term. The other institutional relation hub of data were the coordinative institutions. This gave a picture about the national societies and the institutional framework of educational systems. There are different structures and levels in the national economies, where several coordinative institutions take place, which main or dominant function is to help the operation of universities. We collected and observed those institutions; which profile contains and links to university-business partnering. In this way, we have found institutions, which coordinate the centralized development projects in Hungary aiming to build higher education-industrial cooperation centers. Also, the science centers in Poland and the academies in France, which also have significant role in binding particular parts of higher education and the local firms. These are independent but strongly linked institutions in the national economies serving not only the efficient and practice based educational processes, but also spin off or incubation processes or specific joint research activity. The third pillar of data was information from local industries. All the four cases have rich and long history of their local economies. It was necessary to include local economic input and comparing them to what the universities say about their operation in local dimension. It is always an important question that in what extent a university should integrate its operation into the local market. Our opinion is that nowadays this is one of the key value creation factors of universities. How they can educate people, who's expert fits to the local economies profile. This strengthen their internationalization process as well.

"University-business relations" gave the input for the data of internal operation. Data base here could be divided into five hubs. These hubs cover the university communication toward partnering. The first one is the service placement. Does the university understand its links to the firms as service providing activity? If yes, its extent is very interesting. The other viewpoint is, when a university understood its partnering as long-term cooperation actions, which sometimes does not have tangible outputs more than a joint event or meeting, where plans remain plans. Once a university announces services linked to its firm relations, what kind of services are there? What is the value of them for the institution and for the local society? In case of formalized, long term interactions, what kind of success stories can be discovered in universities' history as outputs? Are there any tangible outcomes? What are the expectations and what are realized? Contact channels are very important data hub in the category of "university-business relations". If we talk about universities, we are talking about institutions with many faculties and departments which have different profiles. Each profile can have formalized action with a local economic player. Always actual question is how the partners find each other in this relation? Are there centralized contact opportunities announced by the institutions, which means that maybe there are only one email address presented on the website? Or there are more contact opportunities divided based on a kind of logic. In case of Germany, where the service opportunities were strongly communicated by the institution, we have found more contact opportunities based on the types of services. In the other cases, there were less detailed entrance channels into a possible cooperation with the educational institution. In order to reveal interdependences with research output we filtered papers from Web of Science and used "number of documents", "number of university-industry co-published papers", the "\% of university-industry copublished papers" as indicators.

In the first round of observation we collected data from 19 cities of 9 countries. In order to highlight the similarities and mostly the differences, we represent the cases of four countries and go into detail of their internal operation. 


\section{EMPIRICAL RESULTS AND DISCUSSION}

Data hubs of Table 1. are compared in the institutions represented in Table 2. First requirement was that, "to be an entrepreneurial university" should be part of the university strategy. Another important requirement was that the chosen universities should be relatively young. Third, small or mid-sized universities were chosen in the multi-case study to provide a relevant dimension in the process of becoming an entrepreneurial university. Other general inclusion requirements were private universities or public universities with decreasing state support and universities from outside the capital regions.

Table 2

Selected cases* Names: Széchenyi István University (SIU), University of Bremen (UB), University of Rennes (UR1), Poznan Technical University (PUT) (2020)

\begin{tabular}{|l|c|c|c|c|}
\hline Country & University* & Nr. of case & Nr. Of students & Founded \\
\hline Hungary & SIU & 1 & 16000 & 1968 \\
\hline Germany & UB & 2 & 20000 & 1971 \\
\hline France & UR1 & 3 & 26000 & 1969 \\
\hline Poland & PUT & 4 & 21000 & 1919 \\
\hline
\end{tabular}

Source: own compilation

In Case 1 currently, Audi has its largest engine and vehicle factory in the world in Györ, the town of SIU, with more than 12000 employees. Its research and development activity, especially in the field of electric engines, is positioned within this region, and the headquarters of its most significant suppliers are also located in the here. The second largest employer in the town is a power supply company with more than 1200 employees. Concerning the university, there is no overall university-business related service placement on the website of the analysed case. The Faculty of Automotive Engineering is the most significant joint venture of the university and its largest local-global partner. The faculty can be understood as an outcome of a long-term relationship, during which several $\mathrm{R} \& \mathrm{D}$ projects, student group works, scientific events and human resource mediation processes have taken place. These are presented as development projects on the website. Thus, university-company links are represented in these projects, including Audi and its suppliers as representatives of industry and external partners (Uni-Györ, 2020). There is no separate range of university services targeting local firms listed on the website, nor is there a formal differentiation between educational activities and university-business services. However, the university is preparing a cooperation center with industrial and other external partners in which wellmanaged desk research introduces real, needs-based university-business cooperation actions to provide services supporting local small- and mid-sized enterprises. An adaptation model has been developed that can be easily applied through knowledge sharing in other higher education institutions by highlighting the role of self-motivating student communities, the local small- and mid-sized business sector and university faculty members.

In Case 2 due to its history (operating since 1971), the UB can be viewed in parallel with Case 1. Bremen's economy has four pillars: the automotive sector, the maritime economy and logistics, wind energy, and the aerospace industry. Bremen is a port and trading city with strong representation in the vehicle industry. The science industry also has strong representation in city marketing. The city's largest firms are Mercedes-Benz, employing 12,700 employees; BLG Logistics, with 6000 employees; and Arcelor Mittal, with 4500 employees. UB has transparent service placement: the university's website introduces general higher education and industrial cooperation activities (Uni-Bremen, 2020) in the "Information for Enterprises" section. Services are grouped according different areas. They are formalized in submenus, and all of them have contact representatives at the university. Whereas in Case 1. we met with project- 
based activity representatives, in this case there was an overall managed university service supply. The contact details provide a direct route for outsider firms or newcomers as well. This type of strategy also includes developing university-company cooperation. The differentiation of classic educational services is clearly visible; on the other hand, formalized, dominating partnerships are not represented at this point. Information about specific university-industry cooperation and relations can be found in the description of several research projects and on faculty websites.

The city examined in Case 3 is Rennes. The industry of the town is dominated by the information technology and automotive sectors. The largest employer is ITC Orange, with 4800 employees. Citroen has been represented since 1961, employing 4000 employees. Rennes Atalante Science and Technology Park is an association representing the IT industry. It stimulates the expansion and location of technology companies, with 280 members employing 20,000 employees. Through "academies", education institutions have the opportunity to form a workforce that meets expectations. Information concerning the UR1 "entrepreneurship, industrial partnership" is available as a submenu on their website under the "Research" menu (Uni-Rennes, 2020). In this case, these university departments function similar to separate institutions that manage all university business activities. In addition, a separate budget allows the departments to manage financial and administrative aspects of the research results. No specific contact name is given in the contact details on the website, and there are several items of news about formalized cooperation. Based on this, we can conclude that the differentiation of university-company services from educational services is at a lower level than in Case 2.

Similar to Case 1, Case 4 underwent a regime change and has had a market-based economy since 1990. Poland joined the European Union in 2004, the same year as Hungary. Poznan is a typical city of the automotive industry. Volkswagen is represented in the city with more than 8000 employees. However, there are two larger employers located in Poznan, a state-owned power supplier company with more than 15,000 employees and a food distributor with 68,000 employees. At the university-industry cooperation level, formalized industrial-higher education cooperation is dominant and can be observed within the automotive industry. The Volkswagen factory is most directly linked to PUT at a national level. Elements of university-company cooperation in communication, similar to Case 1, are visible in development and research projects. Moreover, there are joint lectures and workshops organized at the university; internships, trainees and doctoral programs; grants; courses; and professional events organized by business researchers, executives and science centers. The operation of science centers is closely linked to higher education. Science centers are institutions of higher education and industrial cooperation that adapt to the profile of development areas (e.g., automotive, IT, and medicine). In several cases, these are state or local government-based centers. Their overall task is to provide community services tailored to local industrial needs. Although there is no university-company service placement on the website of the university and only a short description and contact details of development projects can be found (Uni-Poznan, 2020), the science center belonging to the university conducts demand-driven development projects and can serve as a contact point for university-industry cooperation.

\subsection{Case comparison}

To compare the publication output we used the following filters:

- The institutions

- $\quad$ The given year $(2015,2016,2017,2018,2019)$

- All document types

We selected the following indicators for each year: the number of all WoS documents, the number of university-industry co-published papers, the $\%$ of university-industry co-published papers. 
Figure 2 shows the evaluation of all WoS documents for each university. The most productive university is the University of Bremen, followed by Poznan University of technology, University Rennes and the Széchenyi István University. The liner correlation analysis between the year of publishing and the number of WoS documents revealed differences among universities: In case of Poznan we found significantly positive correlation. The number of WoS documents showed positive evolution in case of the University of Bremen and the Széchenyi István University. On contrary, the correlation coefficient was negative in case of the University of Rennes.

- Bremen: Correlation Coefficient $=0.83$ (not significant)

- Poznan: Correlation Coefficient $=0.89\left(^{*}\right)$

- Rennes: Correlation Coefficient $=-0.78$ (not significant, but negative correlation!)

- Széchenyi: Correlation Coefficient $=0.38$

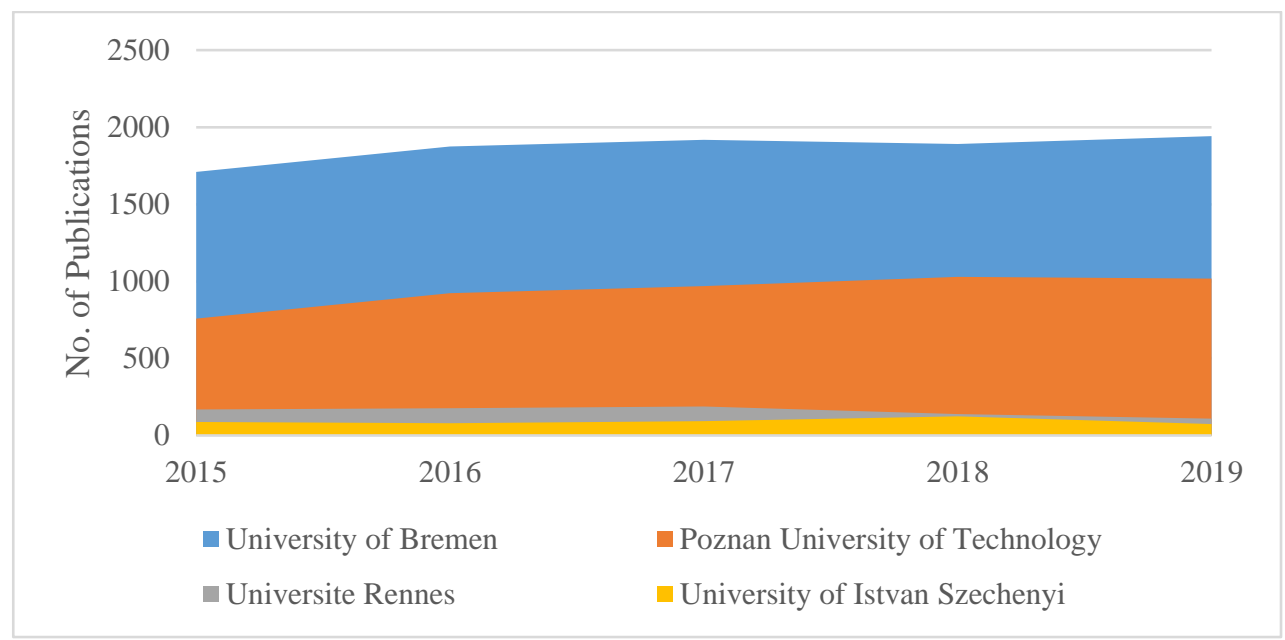

Figure 2. The evaluation of all WoS documents between 2015-2019.

Source: WoS database

Figure 3 shows the evaluation of WoS documents co-published with industrial partners, Figure 4 shows the $\%$ of co-published papers. Please note that whilst the number of co-published papers was the highest in case of University of Rennes, the highest proportion of papers were seen in case of University of Bremen. The evolution of the number and proportion of co-published papers had the similar tendency; therefore, the correlation analysis was performed only in the percentage of co-published papers. Only the Széchenyi István University showed positive correlation, all other universities were characterized by negative correlation.

- Bremen: Correlation Coefficient $=-0.62$ (not significant)

- Poznan: Correlation Coefficient $=-0.25$ (not significant)

- Rennes: Correlation Coefficient $=-0.50$ (not significant)

- Széchenyi: Correlation Coefficient $=0.48$ (not significant) 


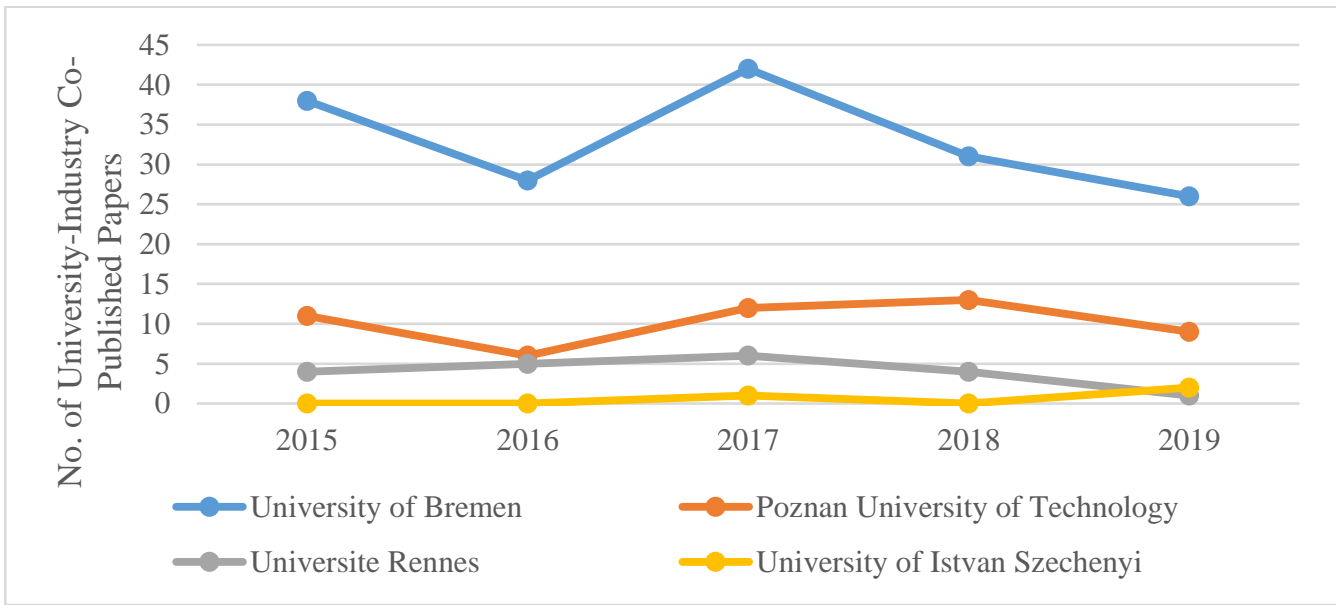

Figure 3. The evolution of university-industry co-published papers between 2015-2019. Source: WoS database

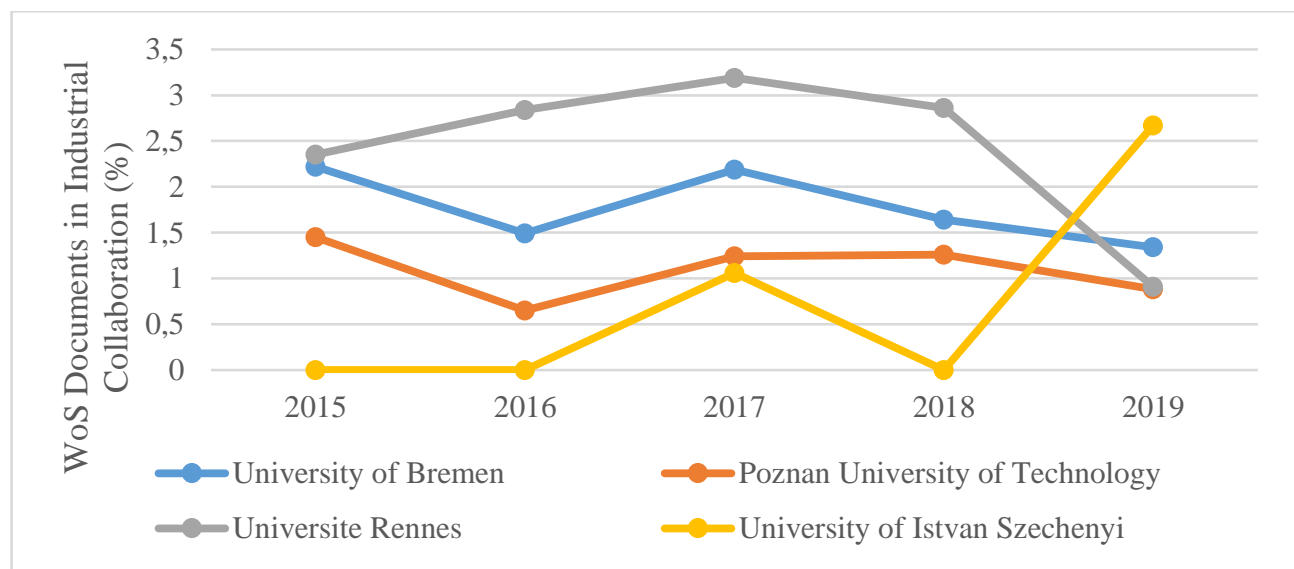

Figure 4. The evolution of university-industry co-published papers (percentage of co-published papers)

Source: WoS database

Specific hypotheses addressed in the case comparison were as follows: There are role differences of universities in the observed cases (H1). There are different understandings behind fruitful universitybusiness partnerships (H2). The rate of diversification in local industries effects the presence and types of university services and business partnering activity $(\mathrm{H} 3)$.

activities. Another important question to understand is how is success measured? The study uses the term "success" in cases of "fruitful partnerships". It is important to understand how universities are able to maintain and sustain their partnerships or increase their quality. Before detailing the conclusion of the cases, the next point highlights the advantages of the application of the grounded theory concept in this case comparison.

The application of the grounded theory concept provided the opportunity to evaluate the commonalities on the bases illustrated in Table 4 through a similarity search ${ }^{1}$.

\footnotetext{
${ }^{1}$ Table 4 is extracted from Table 3.
} 
Table 3

Comparison

\begin{tabular}{|c|c|c|c|c|}
\hline Data Hubs & Case 1 & Case 2 & Case 3 & Case 4 \\
\hline 1/1 (historical b.) & $\begin{array}{l}\text { regime change, } \\
\text { industrial }\end{array}$ & industrial, science & industrial & $\begin{array}{l}\text { regime change, } \\
\text { industrial }\end{array}$ \\
\hline 1/2 (institutional b.) & state & state & state, academies & state, science centers \\
\hline $1 / 3$ (industry) & automotive & automotive, port & automotive, IT & automotive \\
\hline $\begin{array}{l}2 / 1 \text { (service } \\
\text { placement) }\end{array}$ & $\begin{array}{l}\text { webpage-cooperation } \\
\text { center for higher } \\
\text { education and } \\
\text { industry }\end{array}$ & webpage-sub menu & webpage-sub menu & $\begin{array}{c}\text { webpage-science } \\
\text { center }\end{array}$ \\
\hline $2 / 2$ (services) & not listed & $\begin{array}{l}\text { collected in } \\
\text { "university and } \\
\text { business" sub menu } \\
\text { on the webpage. }\end{array}$ & $\begin{array}{c}\text { collected in } \\
\text { "entrepreneurship, } \\
\text { industrial } \\
\text { partnership" sub } \\
\text { menu on the } \\
\text { webpage. }\end{array}$ & not listed \\
\hline $\begin{array}{l}2 / 3 \text { (publication } \\
\text { output) }\end{array}$ & $\begin{array}{c}\text { highest correlation of } \\
\% \text { of collaborative } \\
\text { papers, lowest } \\
\text { number }\end{array}$ & $\begin{array}{c}\text { highest number of } \\
\text { papers, highest ratio } \\
\text { of collaborative } \\
\text { papers }\end{array}$ & $\begin{array}{l}\text { highest number of co- } \\
\text { published papers }\end{array}$ & $\begin{array}{c}\text { High number of } \\
\text { papers, low number } \\
\text { of collaborative } \\
\text { papers }\end{array}$ \\
\hline $\begin{array}{c}\text { 2/4 (nr. of } \\
\text { formalized, long term } \\
\text { partnerships) }\end{array}$ & $\begin{array}{l}\text { high visibility: faculty, } \\
\text { labor, student groups, } \\
\text { research projects with } \\
\text { one partner }\end{array}$ & news & $\begin{array}{c}\text { news (one partner } \\
\text { appears) }\end{array}$ & $\begin{array}{l}\text { high visibility: faculty, } \\
\text { labor, research } \\
\text { projects with one } \\
\text { partner }\end{array}$ \\
\hline $\begin{array}{c}2 / 5 \text { contact } \\
\text { information } \\
\end{array}$ & n.a. & webpage & webpage & n.a. \\
\hline $\begin{array}{c}\text { Rec. cat. (data hubs) - } \\
\text { university role } \\
\text { differences }(1 / 1- \\
2,2 / 1)\end{array}$ & $\begin{array}{l}\text { government - } \\
\text { universities }\end{array}$ & $\begin{array}{l}\text { government - } \\
\text { universities }\end{array}$ & $\begin{array}{l}\text { government - } \\
\text { coordinative } \\
\text { institutions- } \\
\text { universities }\end{array}$ & $\begin{array}{l}\text { government - } \\
\text { coordinative } \\
\text { institutions- } \\
\text { universities }\end{array}$ \\
\hline \multicolumn{5}{|c|}{ Sustainability/success - stronger ties: time frame vs. weaker ties: financial (Arza and Caratolli 2017) } \\
\hline $\begin{array}{l}\text { Rec. cat. (data hubs) - } \\
\text { success }(1 / 1,2 / 1-5)\end{array}$ & long term partners & $\begin{array}{c}\text { wide range of } \\
\text { partners }\end{array}$ & $\begin{array}{l}\text { wide range of } \\
\text { partners }\end{array}$ & long term partners \\
\hline $\begin{array}{c}\text { Rec. cat. (data hubs) - } \\
\text { diversification in } \\
\text { industry }(1 / 1,1 / 3, \\
2 / 1)\end{array}$ & low & high & high & low \\
\hline
\end{tabular}

Source: own compilation

Services in this study refer to activities presented by the university that are not classical educational

Table 4

Similarity search opportunities

\begin{tabular}{|l|l|}
\hline Bases & Similar Cases \\
\hline Strong representation of long-term partnerships & Case 1, Case 4 \\
\hline Moderator institutional level & Case 3, Case 4 \\
\hline University-business service placement directly & Case 2, Case 3 \\
\hline Contact details & Case 3, Case 4 \\
\hline
\end{tabular}

Source: own compilation 
The application of the grounded theory concept also gave the opportunity for the classification of the bases illustrated in Table 5, which led us to the formalization of two opposite directions of universitybusiness partnerships.

Table 5

Classification of the four cases according to Category1 and Category2 - Country specifics of entrepreneurial universities

\begin{tabular}{|l|c|c|}
\hline Recoded categories & Case 1 and Case 4 & Case 2 and Case 3 \\
\hline Role of university & $\begin{array}{c}\text { High level of representing one } \\
\text { cooperative partner, low level of } \\
\text { managed, general cooperation } \\
\text { platforms. }\end{array}$ & $\begin{array}{c}\text { High level of managed, general } \\
\text { cooperation platforms on the } \\
\text { websites, but low level of } \\
\text { representing or highlighting one } \\
\text { main partner. }\end{array}$ \\
\hline Level of length of partnerships & High & Low \\
\hline Diversification $^{2}$ & Low & High \\
\hline
\end{tabular}

Source: own compilation

\section{CONCLUSION}

To summarize the article's contribution to the extant literature with respect to entrepreneurial universities, we should start with the application of the grounded theory concept. Although it is the approach of simple continuous observation, it didn't only provide the opportunity to discover a parallel logic between the existing research concepts (e.g., Guerrero et al. 2012, 2014; Clark 1998) but also provided the opportunity for flexibility in multi-case analysis. Scientific novelty of the paper is that it allowed to apply general comparisons among institutions in a flexible way. There was no conflict due to preconceptions being imposed on the data; rather, we could focus on the categories. The institutional background and university-business interactions were defined as the internal and external research perspectives, respectively. At the same time, the definition of the categories yielded a transparent structure and focus on the case research. The relations between academia and companies is rooted in the cultural aspects of organizations. It is visible in Central and Eastern Europe (Kedziora, 2020; Costa et al. 2020). Short representation of universities' history highlighted those happenings, which contributed to the attitude to business relations. We got the conclusion that local industrial environment shapes the cultural aspects in universities toward business relations.

\subsection{Role differences}

The methodology applied in the study allowed us to discover role differences in the analysed cases. Concerning country specifics, it can be seen that in Germany, in the example case, there is a centralized university-company cooperation phenomenon at the university. The advantage of this is that companies that would like to link to the university can find what they are interested in at the institution. The service character of the university was formed as a service department targeting firms directly. In the French case, the role of academies implemented in secondary education is highlighted by the paper. The system of academies is a well-built knowledge-transforming field. Educational institutions already become involved at a lower level; thus, this may offer the advantage that the entrepreneurial middle-school system prepares stakeholders for the university level. Academies call on businesses; they are the initiators. Firms can

\footnotetext{
${ }^{2}$ Diverse local industry, based on the approximate number of employees differences of the first and second biggest local firms.
} 
choose through the academies the educational institution with which they want to build a collaboration platform. There are services defined on the website targeting businesses, but due to the importance of academies, this link can be regarded as indirect. In the case of Poland, a similar model can be observed in the form of the Science Centers. The difference with the French case is that, due to the announced activities of these centers, they appear to be more autonomous, and their moderator function is highlighted less than in the case of France. Communications from the university do not target firms in a general way with optional services but represent long-term partnerships, especially with the local actors of the automotive industry, as in Case 1, which represents its developing, long-term partnership with the local actors of the automotive industry not only via news but also via university departments and research groups. Consequently, from the represented development projects, there are endeavours across a wide range of partnerships with the local SME sector, as in the German case. The application of the grounded theory concept provided the opportunity to evaluate the commonalities on the cases and also gave the opportunity for the classification (H1).

\subsection{Different notions of success in university-business linkages}

Arza and Carattoli (2017) found that stronger ties bring knowledge benefits and weaker ties provide financial benefits through university services. The above illustrated analysis can raise the question of what we understand about success in terms of university-business linkages. It can be agreed that the notion of fruitful partnerships can be considered differently in the analysed cases. Regarding the duration of a partnership, we note that in the Hungarian and Polish cases, there are key cooperative actions with one main partner. In these cases, the duration is evaluated on a higher level than in that in the cases of the German and French universities, where there are platforms on the website that call the attention of firms in a general way. Following this logic, there are two opposite sides visible from the cases, which is consistent with the findings of Arza and Carattoli (2017). The communication in partnerships clearly illustrates these aspects. For Germany and France, there are service platforms at the universities where extensive partnership creation dominates, attracting the attention of optional partners and showing the financial benefits both from the standpoint of the university and, of course, that of the optional partner firm. In the case of Hungary, there are no general cooperative opportunities yet. There is a development project, for which the general cooperative opportunity is listed on the university website. This formalized platform is under preparation. This can be understood as a step toward the strategic goal of having the responsibility for the general management of university-business partnerships. In the case of Poland, the management of university services is delegated to the science centers; there are no general platforms or university-industry services inside the walls of the university. Both in the Hungarian and Polish cases, the evolution of a few stronger and longer-term partnerships is presented in university communications. Following Arza and Carattoli (2017), knowledge benefits rather than financial benefits can be generated in the Hungarian and Polish cases. In the German and French cases, financial benefits can be generated more directly than knowledge benefits from the service platforms. From this comparison, we can conclude the following about university-business linkages: success can be achieved through a range of partnerships and based on the term of each partnership if we consider the time frame as a measure of duration. In the cases of Hungary and Poland, there are longer partnerships with visible progress and significant output (e.g., the Audi Faculty in the case of Hungary). We can say that the duration is longer in these cases. From the cases of German and French universities, the clear goal is to call the attention of local firms in general. All of the cases have the same goal of valuable partnerships, but two opposite approaches can lead to that the achievement of this goal. One is maintaining partnerships with few main partners for the long term. The other is calling the attention of a wide variety of firms through general 
university services on the websites. In our evaluation long-term partnering is closer to a non-profit point of view and broader service provision support universities position at the same time (H2).

\subsection{Interdependences with diversification in local industry and research output}

Turning to diversification in local industry, the level of employment of the two largest, privately owned, local firms was observed for 2016 for the cases. If we consider the difference between the first and the second largest employer, we can provide an understanding of diversification in the local industry. The study addressed the following hypothesis: The rate of diversification in local industries effects the presence and types of university services and business partnering activity (H3). If we consider the differences in the employment rates, we can see that in the cases of the German and French local industries, differences in employment are slighter than those in the other two countries. Referring to the question of interdependence with the structure of the local industry, we can say that for diversified industries, universities communicate university-business relations in more general ways. In local economies, where there are one or two dominant partners, universities focus more on those firms. Table 6, which shows the classification of the opportunities of the cases, indicates high local industry diversification in the Case 1 and in Case 4 (the Hungarian and Polish cases, respectively) and low local industry diversification in Case 2 and Case 3 (the German and French cases, respectively). To reach a conclusion concerning the interdependencies with the diversification of the local industry, we can say that long-term, fruitful partnerships are presented more often in less diversified local economies. Short-term, service-based university-business relations are presented more often in more diversified local industries. In summary, we observed conscious strategy as a motivating tool in the creation of entrepreneurial universities. In the case studies, we could see different interpretations of this strategy. Based on these case studies, there are two approaches. When valuable partnerships were targeted and there was agreement on the meaning of fruitful partnerships, sustainable partnering and diversification of local industry, significant interdependencies could be observed between the communication of university-business relations and the structure of the local industries. Research output is a usually the consequence of university-business partnering. We can see significant differences in the number of collaborative publications. With the presence of a formalized partnering activity expressed especially by Case 1, we can assume, that number and rate of university-industry co-published papers can start to increase. At the same time, we should note, that high ratio and number of co-published papers is an outcome of a long process and cultural change within the educational institution, which is well presented by Case 2 .

The question is still open - what kind of profits should a university make from a firm partnership. The main income of the universities is coming from tuition fees. Successful partnering provides indirect "profit" for a university, because it can be attractive to perspective students. In this aspect, fruitful partnering is very important and can be formalized in different ways in the different socio-economic environment of universities.

Most importantly, the first limitation should be defined in the question of understanding the term of "diversification". Observations of the diversification of local industries can also be defined as differences in the rate of incomes. We rejected this approach due to different taxing systems. For example, local business tax is not paid directly to the local government in all of the four countries. The second limiting factor is the question of generalizability. The above-mentioned conclusions were made based on four countries and few years. The future research would focus on different economies in Western and Eastern Europe. Through the continued application of the grounded theory approach, more countries will be implemented in the observation. Country replicas can be made to widen the research field. Repeating the observations on time frame is also needed for the cases involved in this article. 


\section{ACKNOWLEDGEMENT}

We are thankful to several participants for their comments on the presentation of previous versions of the paper and to two reviewers, who contributed to the final version of the paper. We are also grateful to representatives of universities and local governments, which have taken part in the data collection. We acknowledge the funding of creating the final version of the paper provided by the European Union and the Hungarian Government in the framework of the Centre for Higher Education and Industrial Cooperation (GINOP-2.3.4-15-2016-00003).

\section{REFERENCES}

Algieri, B., Aquino, A., \& Succurro, M. (2013). Technology transfer offices and academic spin-off creation: The case of Italy. The Journal of Technology Transfer, 38(4), 382-400.

Ankrah, S.N., \& Al-Tabbaa, O. (2015). University-Industry Collaboration: A Systematic Review. Forthcoming: Scandinavian Journal of Management, 31, 387-408

Arza, V., \& Carattoli, M. J (2017). Personal ties in university-industry linkages: a case study from Argentina. Journal of Technology Transfer, 42, 814-840.

Barnes, T., Pashby, I., \& Gibbons, A. (2002). Effective university-industry interaction: A multi-case evaluation of collaborative R\&D projects. European Management Journal, 20(3), 272-285.

Benneworth, P., Boer, H., \& Jongbloed, B. (2015). Between good intentions and urgent stakeholder pressures: institutionalizing the universities' third mission in the Swedish context. European Journal of Higher Education, 3, 280-296.

Charmaz, K. (2003). Grounded theory: Objectivist and Constructivist Methods. Denzin, N.K. - Lincoln, Y.S. (eds.): Strategies of Qualitative Inquiry. Sage Publications, Thousand Oaks.

Charmaz, K. (2006). Constructing Grounded theory. Sage Publications, Thousand Oaks.

Clark, B. (1998). Creating Entrepreneurial Universities: Organizational Pathways of Transformation. Issues in Higher Education. Elsevier Science Regional Sales, NY.

Costa J., Rodrigues A. C., \& Ferreira M.R. (2020). Organizational culture in social economy organizations. Economics and Sociology, 13(3), 155-170. doi:10.14254/2071-789X.2020/13-3/10

Cunningham, J. A, O'Reilly, P. (2018). Macro, meso and micro perspectives of technology transfer. Journal of Technology Transfer, Vol 43, No. 545. https://doi.org/10.1007/s10961-018-9658-4. (downloaded: 04.21.2018).

Czarnitzki, D., Grimpe, C., \& Pellens, M. (2015). Access to research inputs: open science versus the entrepreneurial university. Journal of Technology Transfer, 40, 1050-1063.

Etzkowitz, H. (2003). Innovation in Innovation: The Triple Helix of University-Industry-Government Relations. Social Science Information, 42(3), 293-337

Etzkowitz, H. (2004). The evolution of the entrepreneurial university. International Journal of Technology and Globalization, 1(1), 64-77.

Etzkowitz, H., Leydesdorff, L. (1997). Universities and the Global Knowledge Economy: a Triple Helix of University-IndustryGovernment Relations. London: Pinter.

Etzkowitz, H., \& Leydesdorff. L. (2000). The Dynamics of Innovation: From National Systems and 'Mode 2' to a Triple Helix of University-Industry-Government Relations. Research Policy, 29(2), 109-123

Fekete, D. (2017). Európai jármúipari térségek gazdasági kormányzási modelljei. Tér és társadalom, Vol. 31, No. 3., pp. $125-142$.

Fekete, D. (2018). Economic development and economic governance through the example of the city of Györ. Deturope, 10(1), 97-115.

Fekete, D. (ed.) (2015). New regional economic development methods of European automotive centers. Universitas, Győr.

Ferreira, J. J. M., \& Carayannis, E. G. (2019). University-industry knowledge transfer - unpacking the "black box": an introduction. Knowledge Management Research \& Practive, 17, 353-357 
Ferreira, M. L., \& Ramos, R. (2015). Making university-industry technological partner ships work: A case study in the Brazilian oil innovation system. Journal of Technology Management and Innovation, 10(1), 173-187.

Filippetti, A., \& Savona, M. J. (2017). University-industry linkages and academic engagements: individual behaviours and firms' barriers. Introduction to the special section. Journal of technology transfer. https://doi.org/10.1007/s10961-017-9576-x (downloaded: 04.21.2018).

Fuller, D., Beynon, M., \& Pickernell, D. (2019). Indexing third stream activities in UK universities: eyploring the entrepreneurial/enterprising university. Studies in Higher Education. 44(1), 86-110. doi:10.1080/03075079.2017.1339029

Glaser, A., o'Shea, N., \& de Gery, C. (2014). Measuring Third Mission Activities of Higher Education Institutes. Constructing and Evaluation Framework. British Academy of Management (BAM) conference, Belfast, Northern Ireland.

Glaser, B.G. (1978). Theoretical sensitivity: Advances in Methodology of Grounded theory. Sociology Press, Mill Valley.

Glaser, B.G. (1998). Doing Grounded Theory: Issues and Discussions. Sociology Press, Mill Valley.

Glaser, B.G., \& Strauss A.L. (1967). The discovery of grounded theory. Strategies for qualitative research. Routledge. New York, USA.

Glaser, B.G., \& Strauss A.L. (2017). The discovery of grounded theory. Strategies for qualitative research. Routledge. New York, USA.

Guadix, J., Carrillo-Castrillo, J., Onieva, L., \& Navascués, J. (2016). Success variables in science and technology parks. Journal of Business Research, 69(11), 4870-4875. https://doi.org/10.1016/j.jbusres.2016.04.045.

Guerrero, M. Urbano, D., Fayolle, A., \& Sarfraz M. (2016). Entrepreneurial universities: emerging models in the new social and economic landscape. Small Business Economics, 47, 551-563

Guerrero, M., \& Urbano, D. (2012). The development of an entrepreneurial university. Journal of Technology Transfer, 37, 43-74.

Guerrero, M., Urbano, D., Cunningham, J., \& Organ, D. (2014). Entrepreneurial universities in two European regions: a case study comparison. Journal of Technology Transfer, 39, 415-434

Inzelt, A. (2004). The evolution of university-industry-government relationships during transition. Research Policy, 33 (6-7), 975-995.

Jacob, M., Lundqvist, M., \& Hellsmark, H. (2003). Entrepreneurial transformations in the Swedish University system: The case of Chalmers University of Technology. Research Policy, 32(9), 1555-1568.

Kedziora D. (2020). Organizational culture of offshore service centres in Central and Eastern Europe, in (Eds: I. \& L. Warter), Understanding Culture and Ethics in Organizations: A Study of Eastern and Central Europe Emerald Publishing Limited

Kedziora, D., Klamut, E., Karri, T., \& Kraslawski, A. (2017). Higher education offshoring as an innovative response to global learning challenges. International Journal of Management, Knowledge and Learning, 6(2), 239-360.

Kohus, Z., Baracskai, Z., \& Czakó, K. (2020). The Relationship between University-Industry Co-Publication Outputs. Conference paper: 58 $8^{\text {th }}$ International Scientific Conference on Economic and Social Development Budapest, 04-05 September, 2020

Laredo, P. (2007). Revisiting the Third Mission of Universities: Toward a Renewed Categorization of University Activities? Higher Education Policy, 20(4), 441-456

Martin, P. Y., \& Turner, B. A. (1986). Grounded theory and organizational research. The journal of applied behavioral science, 22(2), 141-157.

Martinelli, A., Meyer, M., \& Tunzelmann, N. (2008). Becoming an entrepreneurial university? A case study of knowledge exchange relationships and faculty attitudes in a medium-sized, research-oriented university. Journal of Technology Transfer, 33, 259-283.

Perkmann, M., Neely, A., \& Walsh, K. (2011). How Should Firms Evaluate Success in University-Industry Alliances? A Performance Measurement System. R\&D Management, 41(2), 202-216

Pertuze, J., Calder, E.S., Greitzer, E.M., Lucas W.A. (2010). Best Practices of University-Industry Collaboration. MIT Sloan Management Review, 51(4), 83-90.

Piirainen, K. A., Andersen, A. D., \& Andersen, P. D. (2016). Foresight and the Third Mission of Universities: the Case for Innovation System Foresight. Foresight, 18(1), 24-40. 
Powers, J., \& McDougall, P. (2005). University start-up formation and technology licensing with firms that go public: A resource based view of academic entrepreneurship. Journal of Business Venturing, 20(3), 291-311.

Rasmussen, E., \& Rice, M. P. (2011). A framework for government support mechanisms aimed at enhancing university technology transfer: The Norwegian case. International Journal of Technology Transfer and Commercialisation, 11(1-2), 1-25.

Sbaraini, A., Carter, Evens, R.W., \& Blinkhorn, A. (2011). How to do a grounded theory study: a worked example of a study of dental practices. BMC Medical Research Methodology 2011, Vol. 11, No. 128 http://www.biomedcentral.com/1471-2288/11/128 (downloaded: 01. 04. 2018)

Stankevičiené, J., Maditinos, D. I., \& Kraujaliené, L. (2019). MULTIMOORA as the instrument to evaluate the technology transfer process in higher education institutions. Economics and Sociology, 12(2), 345-360. doi:10.14254/2071-789X.2019/12-2/21Strauss, A.L. (1987). Qualitative Analysis for Social Scientists. Cambridge University Press, Cambridge.

Tijssen, E. (2012). Joint Research Publications: A Performance Indicator of University-Industry Collaboration. Assessment \& Evaluation in Higher Education, 5(2), 19-40.

Tijssen, R., Van Leeuwen, T., \& Wijk E.V. (2009). Benchmarking University-Industry Research Cooperation Worldwide: Performance Measurements and Indicators Based on Co-Authorship Data for the World's Largest Universities. Research Evaluation, 18(1), 13-24.

Uni-Bremen. (2020). http://www.uni-bremen.de/en/enterprises.html (downloaded: 01.02.2020).

Uni-Győr. (2020). http://admissions.sze.hu/welcome (downloaded: 01.02.2020).

Uni-Poznan. (2020). https://www4.put.poznan.pl/en/projekty/research-and-development-projects (downloaded: $01.02 .2020)$.

Uni-Rennes. (2020). https://international.univ-rennes1.fr/entrepreneurship-ecosystem-rennes-and-brittany (downloaded: 01.02.2020).

Uslu, B. (2018). Strategic actions and strategy changes in European universities: clues from institutional evaluation reports of the European University Association. European Journal of Higher Education, 8(2), 215-29. 